\title{
Pengaruh Perceived Enjoyment, Perceived Reciprocal Benefit, dan Learning Culture Terhadap Knowledge Sharing
}

\author{
Debby Ummul Hidayah*, Ika Romadoni Yunita, Masyruri Riska Maulana \\ Sistem Informasi, Fakultas Ilmu Komputer, Universitas Amikom Purwokerto, \\ Jl. Letjend Pol. Soemarto No.126, Kec. Purwokerto Utara, Kabupaten Banyumas, Jawa Tengah 53127 \\ *e-mail: debbyummul@amikompurwokerto.ac.id
}

(received: 19 Juli 2021, revised: 8 Agustus 2021, accepted: 29 Agustus 2021)

\begin{abstract}
Abstrak
Adanya pandemik COVID-19 mengharuskan perkuliahan dilakukan secara online. Hal tersebut dialami juga oleh Universitas XYZ yang menerapkan sistem kuliah online menggunakan beberapa media seperti website kuliah online, google classroom, zoom, google meet, dan platform lainnya yang disesuaikan dengan kesepakatan antara dosen dengan mahasiswa. Namun berbagai permasalahan muncul terutama mekanisme knowledge sharing dalam perkuliahan online. Oleh sebab itu, peneliti melakukan uji dengan menggunakan variabel perceived enjoyment, perceived reciprocal benefit, dan learning culture guna mengetahui bagaimana pengaruh dari ketiga variabel independen tersebut terhadap variabel dependen. Metode penelitian yang digunakan yakni menggunakan pendekatan kuantitatif. Berdasarkan hasil sebaran kuesioner dengan jumlah sampel 160 dari mahasiswa program studi Sistem Informasi Universitas XYZ dan analisis data menggunakan SPSS 22, hasilnya menunjukkan bahwa variabel perceived enjoyment menjadi faktor utama yang berpengaruh terhadap knowledge sharing. Atau dapat dikatakan bahwa variabel perceived enjoyment berpengaruh positif terhadap variabel knowledge sharing. Kemudian variabel learning culture juga memiliki pengaruh posiftif terhadap knowledge sharing. Adapun variabel perceived reciprocal benefit tidak memiliki pengaruh yang kuat terhadap knowledge sharing.
\end{abstract}

Kata kunci: Perceived enjoyment, perceived reciprocal benefit, learning culture, knowledge sharing, kuliah online

\begin{abstract}
The existence of the COVID-19 pandemic requires learning to be conducted online. This is also experienced by XYZ University which implements an online learning system using several media such as online learning websites, google classroom, zoom, google meet, and other platforms that are adjusted to the agreement between lecturers and students. However, various problems arise, especially the knowledge sharing mechanism in online learning. Therefore, the researcher conducted a test using the variables perceived enjoyment, perceived reciprocal benefit, and learning culture to find out how the influence of the three independent variables on the dependent variable. The research method used is a quantitative approach. Based on the results of the distribution of the questionnaire with a sample of 160 from students of the Information Systems study program at XYZ University and data analysis using SPSS 22, the results show that the perceived enjoyment variable is the main factor that influences knowledge sharing. Or it can be said that the perceived enjoyment variable has a positive effect on the knowledge sharing variable. Then the learning culture variable also has a positive influence on knowledge sharing. The perceived reciprocal benefit variable does not have a strong influence on knowledge sharing.
\end{abstract}

Keywords: Perceived enjoyment, perceived reciprocal benefit, learning culture, knowledge sharing, online learning 


\section{Pendahuluan}

Awal bulan Maret 2020 Indonesia dikejutkan dengan hadirnya virus covid-19 yang terdeteksi dari 2 kasus pasien dinyatakan positif covid-19. Kondisi tersebut menjadi perhatian penuh bagi pemerintah sekaligus masyarakat guna siap siaga untuk ikut bergotong royong dalam mengatasi bencana pandemik covid-19. Tidak dipungkiri, bahwa kondisi pandemik covid-19 mulai meluas di berbagai wilayah Indonesia. Hal ini terbukti dari banyaknya korban yang terindikasi virus covid-19. Bermula dari puluhan, ratusan, ribuan, dan sampai jutaan. Kehidupan baru dalam dunia kerja, pendidikan, ekonomi dan bidang lainnya pun ikut terdampak pandemik covid-19.

Dalam dunia pendidikan, khususnya di suatu perguruan tinggi, Kemenristekdikti memberikan regulasi berupa pembelajaran secara daring yang dapat dilakukan oleh penyelenggara pendidikan baik tingkat swasta maupun negeri. Tidak dipungkiri pula bahwa perkuliahan secara daring atau online memegang peranan untuk pendidikan di masa depan [1]. Adapun pemerintah pun juga harus harus memastikan ketersediaan alat komunikasi yang andal, pengalaman akademik digital berkualitas tinggi, dan mendorong pembelajaran berteknologi bagi mahasiswa untuk menjembatani kesenjangan yang berasal dari sistem pendidikan sebelum dan sesudah pandemik COVID-19 untuk menghindari berbagai ancaman dalam proses pembelajaran [2].

Sejalan dengan regulasi yang ada, salah satu kampus swasta di Jawa Tengah yakni Universitas $\mathrm{XYZ}$ pun turut menjalankan perkuliahan secara daring atau online. Berdasarkan observasi secara langsung, media yang digunakan untuk mendukung kegiatan perkuliahan online diantaranya website kuliah online, google classroom, zoom, google meet, dan platform lainnya yang disesuaikan dengan kesepakatan antara dosen dengan mahasiswa. Selain itu media lain yang juga digunakan untuk menunjang pemahaman materi perkuliahan adalah video yang berdurasi minimal 15 menit. Video tersebut berguna untuk membantu mahasiswa dalam memperoleh tacit knowledge berupa pengalaman, pemikiran, kompetensi, komitmen, dan keahlian yang dapat diterapkan dalam mengerjakan suatu tugas tertentu [3].

Sehingga dapat disimpulkan bahwa mekanisme perkuliahan yang dilakukan merupakan suatu cara atau teknik untuk memudahkan dalam berbagi pengetahuan kepada mahasiswa. Berbagi pengetahuan merupakan suatu proses untuk mengkomunikasikan pengetahun tacit atau explicit kepada orang lain [4]. Mekanisme dalam berbagi pengetahuan seperti socialization adalah salah cara untuk berbagi pengetahuan tacit. Sedangkan mekanisme lainnya adalah exchange atau pertukaran merupakan proses untuk berbagi pengetahuan explicit. Dalam penelitian ini, kedua mekanisme tersebut dapat diterapkan guna meningkatkan pengetahuan bagi mahasiswa. Sebagai contoh ketika dosen menjelaskan ilmu pengetahuan atau memberikan sesi tanya jawab kepada mahasiswa pada saat melakukan perkuliahan menggunakan meeting online maka hal tersebut dapat menjadikan mahasiswa untuk lebih berpartisipasi aktif. Dalam hal ini meeting online dengan menggunakan video conference dapat dipandang sebagai faktor yang mampu memengaruhi kinerja mahasiswa [5]. Meskipun demikian penerapan meeting online seperti melalui video conferencing tidak serta merta memberikan feedback yang baik untuk beberapa matakuliah [6]. Terutama pada matakuliah yang berbasis praktik. Selain itu alternatif lain untuk perkuliahan adalah melalui forum, dosen dapat memberikan pertanyaan dalam bentuk studi kasus untuk membantu mahasiswa mampu berfikir secara kritis. Sebuah temuan juga menjelaskan bahwa diskusi online mampu mendorong pembelajaran yang mendalam dengan syarat pendidik harus mampu memberikan pedoman yang jelas dan tenggat waktu untuk berdiskusi [7]. Video pembelajaran pun dapat menjadi media pendukung perkuliahan forum tersebut. Modul berupa softcopy juga dapat digunakan sebagai media berbagi pengetahuan explicit, dan mendukung untuk meningkatkan kinerja akademik mahasiswa [8]. Selain itu pemberian kuis di akhir perkuliahan juga berperan untuk meningkatkan efektivitas pembelajaran [9]. Demikian juga dengan multimedia dapat menjadi alat pembelajaran yang praktis [10].

Pada penelitian ini, peneliti mencoba mengkuantifikasi isu permasalahan yang berkaitan dengan aktifitas berbagi pengetahuan pada mahasiswa program studi Sistem Informasi angkatan 2018, 2019, dan 2020 di Universitas XYZ. Berdasarkan pengamatan di lapangan muncul berbagai permasalahan terkait penerapan dari mekanisme berbagi pengetahuan dalam kegiatan perkuliahan yang sudah dilakukan. Berbagi pengetahuan penting untuk dikaji sebab paradigma berbagi pengetahuan adalah 
membagikan pengetahuan yang dimiliki oleh satu individu kepada individu lain sehingga diantara keduanya dapat terjadi interaksi yang saling menguntungkan satu sama lain. Apabila pengetahuan hanya untuk diri sendiri maka pengetahuan tersebut akan lebih mudah hilang. Namun, jika pengetahuan disebarkan dan didokumentasikan maka pengetahuan dapat digunakan kembali dan dapat diperbaharui. Dalam suatu penelitian menjelaskan bahwa untuk dapat memotivasi para peserta didiknya (misalnya mahasiswa) guna membagikan ilmunya (pengetahuan) maka ada beberapa faktor yang berpengaruh yakni pengetahuan peserta didik, pengetahuan pengajar, dan konteks mata pelajaran atau mata kuliah [20]. Sebagai contoh dengan mengadakan pembelajaran berbasis kasus. Hal tersebut dapat menjadi cara untuk bisa memanfaatkan pengetahuan dan keterampilan yang dimiliki oleh peserta didik. Sebab para peserta didik dapat mengembangkan kreasi pengetahuan dengan berbagi pengetahuan dan memperluas pengetahuan melalui mekanisme tacit knowledge menjadi explicit knowledge. Oleh sebab itu, sudah seharusnya penyelenggara pendidikan (sekolah ataupun universitas) perlu mendorong untuk meningkatkan berbagi pengetahuan antar peserta didiknya dengan merancang berbagai kegiatan sehingga dapat menciptakan kesadaran akan manfaat dari berbagi pengetahuan [12]. Knowledge sharing dapat dilakukan dengan mengelola pengetahuan tacit atau explicit melalui serangkaian mekanisme tertentu seperti sosialisasi, kemudian interaksi ataupun pelatihan [18]. Oleh sebab itu knowledge sharing dapat dikatakan efektif apabila melibatkan proses transmisi maupun penyerapan pengetahuan oleh pengirim atau penerima pengetahuan. Pembentukan CoP (Community of Practice) juga dapat dijadikan strategi untuk memfasilitasi knowledge sharing dalam membangun intelektual kapital pendidikan [19]. Di samping itu penggunaan teknologi juga berperan sebagai piranti yang mendukung untuk berbagi pengetahuan. Seperti dalam perkuliahan online, pengetahuan dapat dibagikan secara langsung melalui video conference atau melalui forum. Akan tetapi dalam praktiknya, penggunaan teknologi dapat menjadi hambatan dalam proses berbagi pengetahuan. Seperti masalah jaringan terputus atau listrik padam yang mengakibatkan mahasiswa tidak bisa mengikuti perkuliahan online. Di samping itu, kurangnya partisipasi aktif mahasiswa di kuliah forum yang mengakibatkan perkuliahan menjadi kurang efektif dan materi yang diserap tidak optimal. Permasalahan lain juga terjadi ketika dosen menjelaskan materi secara conferencing namun banyak mahasiswa yang justru meninggalkan perkuliahan meskipun tertera online pada list peserta.

Mengacu dari penjelasan di atas, peneliti tertarik untuk melakukan penelitian dengan menganalisis faktor-faktor yang dapat mempengaruhi berbagi pengetahuan (knowledge sharing) dalam kaitannya dengan pembelajaran secara online. Faktor-faktor yang digunakan diadaptasi dari penelitian [11] [12] yaitu faktor perceived enjoyment yang digunakan untuk memprediksi tingkat kenyamanan untuk berbagi pengetahuan menggunakan kuliah online dan perceived reciprocal benefit yang digunakan untuk mengetahui sejauh mana seseorang dapat percaya bahwa mereka mampu memperoleh manfaat bersama melalui berbagi pengetahuan. Faktor lainnya diadaptasi dari penelitian [13] [14] yaitu learning culture yang memiliki peran penting dalam proses persiapan belajar dengan menanamkan tingkat kesiapan dan kemauan antar individu.

Peneliti memilih variabel perceived enjoyment sebab variabel tersebut dapat digunakan untuk menunjukkan bahwa adanya rasa percaya atau trust saat menggunakan sistem dan dapat dianggap sebagai suatu kegiatan yang menyenangkan [15]. Dengan adanya rasa percaya terhadap pengetahuan yang dibagikan melalui forum atau video conference dapat menjadi sumber motivasi instrinsik dengan memberikan penekanan pada proses penggunaan dan pencerminan dari kenyamanan seseorang serta adanya kenikmatan saat menggunakan sistem [16]. Tentunya apabila seseorang merasakan kenyamanan saat menggunakan sistem, mereka akan termotivasi untuk menggunakan sistem itu kembali. Maka dikatakan bahwa perceived enjoyment memiliki implikasi yang baik dalam menunjang proses berbagi pengetahuan.

Alasan kedua, peneliti memilih menggunakan variabel reciprocal benefit yakni untuk menunjukkan bahwa dengan penggunaan sistem yang baik, maka bisa menguntungkan seseorang (dalam hal ini adalah mahasiswa). Mereka dapat peroleh pengetahuan untuk menciptakan suatu inovasi. Selain itu reciprocal benefit merujuk pada suatu jenis keuntungan yang ingin diperoleh individu dari tindakan yang dilakukan pada saat ini untuk masa depan [17]. Hal tersebut dapat tercermin apabila dalam suatu perkuliahan mahasiswa senang untuk saling berbagi pengetahuan dan 
membantu dalam memecahkan suatu masalah tentunya akan memberikan keuntungan bagi semuanya. Mahasiswa yang awalnya kesulitan memahami suatu materi dapat menjadi lebih paham dengan arahan dari temannya. Sehingga, mahasiwa bersangkutan dapat lebih yakin untuk memperoleh nilai akhir yang baik.

Alasan ketiga, peneliti memilih varibael learning culture sebab unsur budaya dapat menunjukkan suatu konvensi, value, praktik, dan juga proses organisasi guna mendorong individu maupun organisasi untuk dapat mengembangkan pengetahuan sekaligus kompetensi yang dimiliki [14]. Selain itu menurut [13] menjelaskan bahwa learning culture memiliki pengaruh yang signifikan terhadap niat seseorang untuk berbagi pengetahuan. Hal tersebut dapat mengindikasikan bahwa budaya dapat dilihat sebagai suatu nilai dan sistem yang secara langsung dapat mempengaruhi kualitas pembelajaran individu. Menerapkan learning culture untuk berbagai pengetahuan akan menjadikan seseorang menjadi terlatih untuk membiasakan diri dalam menyerap ataupun berbagi pengetahuan. Seperti dengan memberikan reward berupa nilai bonus kepada mahasiswa yang senantiasa aktif pada setiap perkuliahan. Contoh lainnya seperti penerapan budaya untuk membaca naskah pendek atau video pembelajaran pada awal perkuliahan kemudian diadakan sesi tanya jawab. Apabila ada mahasiswa yang tidak mengikuti aturan tersebut dapat berakibat pada nilai yang tidak maksimal.

Dari beberapa alasan yang ada, maka penelitian ini memiliki tujuan untuk mengetahui bagaimana pengaruh variabel perceived enjoyment, perceived reciprocal benefit, dan learning culture terhadap knowledge sharing pada kuliah online di Universitas XYZ. Sehingga dengan mengetahui tingkat pengaruh yang dari ketiga variabel independen tersebut dapat menjadi salah satu pendekatan untuk memperbaharui mekanisme yang saat ini sedang berjalan pada kuliah online Universitas XYZ menjadi lebih efektif dan produktif.

\section{Tinjauan Literatur}

\section{a. Knowledge Sharing}

Knowledge sharing merupakan suatu bentuk komunikasi dari semua jenis pengetahuan baik pengetahuan tacit atau explicit melalui serangkaian mekanisme tertentu seperti sosialisasi. Interaksi, ataupun pelatihan [18]. Oleh sebab itu knowledge sharing dapat dikatakan efektif apabila melibatkan proses transmisi maupun penyerapan pengetahuan oleh pengirim atau penerima pengetahuan. Dalam konteks pendidikan, sharing knowledge atau berbagi pengetahuan menjadi salah satu cara untuk menjadikan kelas lebih aktif dan juga mereka dapat mengembangkan pengetahuan yang dimilikinya. Dalam suatu penelitian menjelaskan bahwa untuk dapat memotivasi para peserta didiknya (misalnya mahasiswa) guna membagikan ilmunya (pengetahuan) maka ada beberapa faktor yang berpengaruh yakni pengetahuan peserta didik, pengetahuan pengajar, dan konteks mata pelajaran atau mata kuliah [20]. Sebagai contoh dengan mengadakan pembelajaran berbasis kasus. Hal tersebut dapat menjadi cara untuk bisa memanfaatkan pengetahuan dan keterampilan yang dimiliki oleh peserta didik. Sebab para peserta didik dapat mengembangkan kreasi pengetahuan dengan berbagi pengetahuan dan memperluas pengetahuan melalui mekanisme tacit knowledge menjadi explicit knowledge. Oleh sebab itu, sudah seharusnya penyelenggara pendidikan (sekolah ataupun universitas) perlu mendorong untuk meningkatkan berbagi pengetahuan antar peserta didiknya dengan merancang berbagai kegiatan sehingga dapat menciptakan kesadaran akan manfaat dari berbagi pengetahuan [12].

\section{b. Perceived Enjoyment}

Menurut [15] menjelaskan bahwa perceived enjoyment menunjukkan bahwa adanya rasa percaya saat menggunakan sistem dapat dianggap sebagai suatu kegiatan yang menyenangkan. Perceived enjoyment juga dapat dikatakan sebagai motivasi instrinsik dengan memberikan penekanan pada proses penggunaan dan pencerminan dari kenyamanan seseorang serta adanya kenikmatan saat menggunakan sistem [16]. Tentunya apabila seseorang merasakan kenyamanan saat menggunakan sistem, mereka akan termotivasi untuk menggunakan sistem itu kembali. Sehingga dapat dikatakan bahwa perceived enjoyment memiliki implikasi yang baik dalam penggunaan sistem. Adapun hipotesis yang dapat diasumsikan yaitu: 

sharing

H1 : Terdapat pengaruh positif yang signifikan antara perceived enjoyment dengan knowledge

\section{c. Perceived Reciprocal Benefit}

Reciprocal atau timbal balik merupakan suatu proses di mana seseorang dapat mengakses dan menggunakan informasi eksternal untuk memperoleh inovasi. Sedangkan reciprocal benefit merupakan suatu jenis keuntungan yang ingin diperoleh individu dari tindakan yang dilakukan pada saat ini untuk masa depan [17]. Adapun hipotesis yang dapat diasumsikan yaitu:

$\mathrm{H} 2$ : Terdapat pengaruh positif yang signifikan antara perceived reciprocal benefit dengan knowledge sharing

\section{d. Learning Culture}

Learning culture merupakan suatu kumpulan konvensi, value, praktik, dan juga proses organisasi guna mendorong individu maupun organisasi untuk dapat mengembangkan pengetahuan sekaligus kompetensi yang dimiliki [14]. Menurut penelitian yang dilakukan oleh [13] menjelaskan bahwa learning culture memiliki pengaruh yang signifikan terhadap niat seseorang untuk berbagi pengetahuan. Hal tersebut dapat mengindikasikan bahwa budaya dapat dilihat sebagi suatu nilai dan sistem yang secara langsung dapat mempengaruhi kualitas pembelajaran individu. Adapun hipotesis yang dapat diasumsikan yaitu:

H3 : Terdapat pengaruh positif yang signifikan antara learning culture dengan knowledge sharing

\section{e. Penelitian Terdahulu}

Penelitian pertama pernah dilakukan oleh [12] dengan judul penelitian "impact of social networking and technology on knowledge sharing among undergraduate students". Penelitian tersebut bertujuan untuk mengetahui faktor-faktor yang mempengaruhi berbagi pengetahuan di antara mahasiswa. Sebab berbagi pengetahuan yang efektif dan inklusif merupakan proses yang sangat integral bagi suatu pembelajaran di suatu Universitas. Metode penelitian yang digunakan menggunakan survei dengan menyebarkan kuesioner untuk memperoleh data. Hasilnya menunjukkan bahwa variabel files-sharing, perceived enjoyment, perceived reciprocal benefit, dan ICT berpengaruh positif terhadap sharing knowledge di antara mahasiswa.

Penelitian kedua dilakukan oleh [13] dengan judul penelitian "IT usage, perceived knowledge usefulness, learning culture and intention to share knowledge among business students in a Malaysian Public University". Penelitian tersebut memiliki tujuan untuk mengetahui faktor-faktor yang mempengaruhi niat untuk berbagi pengetahuan pada mahasiswa. Metode yang digunakan dalam penelitian ini menggunakan pendekatan studi korelasional untuk mengetahui hubungan penggunaan TI, persepsi kegunaan pengetahuan dan budaya belajar dengan niat berbagi pengetahuan. Adapun hasil penelitian menunjukkan bahwa faktor learning culture dan perceived knowledge usefulness memiliki relasi yang signifikan dengan niat untuk share knowledge (berbagi pengetahuan).

Penelitian ketiga pernah dilakukan oleh [11] dengan judul penelitian "the impact of perceived enjoyment, perceived reciprocal benefits and knowledge power on students' knowledge sharing through facebook". Penelitian tersebut memiliki tujuan untuk mengetahui keterkaitan antara variabel perceived enjoyment, perceived reciprocal benefits, perceived status, outcome expectation, dan the power of knowledge dalam mempengaruhi knowledge sharing di antara peserta didik. Metode penelitian yang digunakan menggunakan metode penelitian kuantitatif dengan menyebarkan kuesioner dan melakukan survei untuk memperoleh data. Hasil penelitian ini menunjukkan bahwa variabel perceived reciprocal benefit dan variabel perceived enjoyment merupakan faktor utama yang mempengaruhi sharing knowledge. 


\section{Metode Penelitian}

\section{a. Sampel dan Prosedur}

Pada penelitian ini, responden yang akan dijadikan sampel penelitian merupakan mahasiswa/i yang berada di program studi (prodi) sistem informasi Universitas XYZ. Adapun jumlah populasi yang digunakan sebanyak 400 yang terdiri dari angkatan 2018, 2019 dan 2020. Sedangkan pengambilan sampel digunakan metode convenience sampling yakni merupakan teknik pengambilan sampel secara kebetulan [21]. Kuesioner akan disebarkan ke tiap-tiap angkatan khususnya mahasiswa/i prodi sistem informasi dengan memperhatikan siapa yang mau bersedia mengisi kuesioner. Dari hasil penyebaran kuesioner, jumlah sampel yang diperoleh yakni 160 sampel.

\section{b. Variabel}

Penelitian ini merupakan penelitian kuantitatif dengan menggunakan kuesioner dan survei untuk mengumpulkan data. Item yang digunakan terlihat pada tabel 1 sampai dengan tabel 4. Untuk menilai variabel perceived enjoyment dan perceived repicrocal benefit diadopsi dari penelitian [11] dan [12]. Kemudian item yang digunakan untuk menilai variabel learning culture diadopsi dari penelitian [13]. Terakhir item yang digunakan untuk menilai variabel knowledge sharing diadopsi dari penelitian [11]. Gambar 1 menunjukkan model hubungan antar variabel yang digunakan.

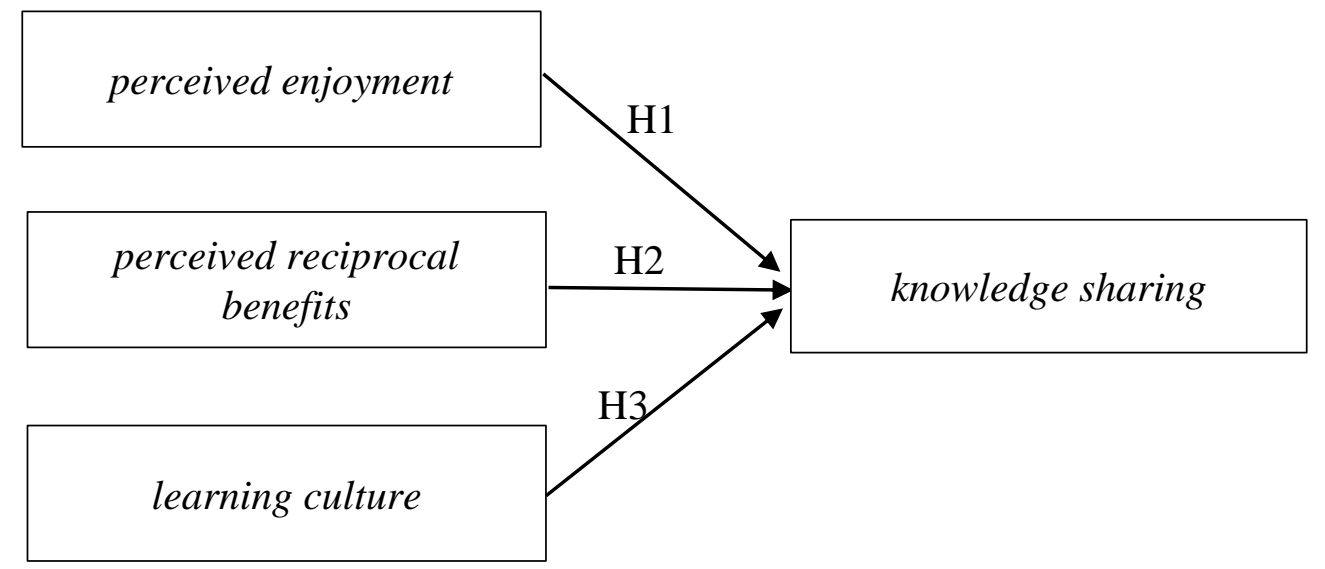

Gambar 1. Hubungan Antar Variabel

Sedangkan untuk pengukuran tiap item digunakan skala likert lima poin yakni dari 1 (sangat tidak setuju) sampai 5 (sangat setuju).

Tabel 1. Instrumen Penelitian Variabel Perceived Enjoyment

\begin{tabular}{ll}
\hline Item & Pernyataan \\
\hline PE1 & $\begin{array}{l}\text { Saya merasa nyaman ketika berbagi pengetahuan menggunakan online } \\
\text { learning. }\end{array}$ \\
PE2 & $\begin{array}{l}\text { Saya merasa bahagia ketika berbagi pengetahuan menggunakan online } \\
\text { learning. }\end{array}$ \\
PE3 & $\begin{array}{l}\text { Saya merasa nyaman berbagi pengetahuan dengan teman saya di online } \\
\text { learning. }\end{array}$ \\
PE4 & $\begin{array}{l}\text { Saya merasa senang bisa membantu teman dengan membagikan pengetahuan } \\
\text { saya di online learning. }\end{array}$ \\
PE5 & $\begin{array}{l}\text { Berbagi pengetahuan dengan teman sangat bermanfaat secara personal. } \\
\text { PEay merasa senang bisa berbagi pengetahuan dengan teman di online } \\
\text { learning. }\end{array}$ \\
\hline
\end{tabular}


Tabel 2. Instrumen Penelitian Variabel Perceived Reciprocal Benefit

\begin{tabular}{ll}
\hline Item & Pernyataan \\
\hline PR1 & $\begin{array}{l}\text { Jika saya berbagi pengetahuan dengan teman di online learning, mereka juga } \\
\text { akan membantu saya menjawab pertanyaan jika saya bertanya. }\end{array}$ \\
PR2 & $\begin{array}{l}\text { Jika saya berbagi pengetahuan dengan teman di online learning, saya berharap } \\
\text { mereka dapat berbagi pengetahuan dengan saya di waktu mendatang. }\end{array}$ \\
PR3 & $\begin{array}{l}\text { Teman saya akan membantu saya jika saya membantu mereka memecahkan } \\
\text { masalah di online learning. }\end{array}$ \\
PR4 & $\begin{array}{l}\text { Teman saya akan berbagi pengetahuan dengan saya jika saya berbagi } \\
\text { pengetahuan dengan mereka di online learning. } \\
\text { PR5 }\end{array}$ \\
& $\begin{array}{l}\text { Saya harus berbagi pengetahuan dengan teman saya jika mereka berbagi } \\
\text { pengetahuan dengan saya di online learning. }\end{array}$ \\
\hline
\end{tabular}

Tabel 3. Instrumen Penelitian Variabel Learning Culture

\begin{tabular}{|c|c|}
\hline Item & Pernyataan \\
\hline $\mathrm{LC} 1$ & Di kampus saya, mahasiswa akan diberi penghargaan dalam proses pembelajaran. \\
\hline LC2 & $\begin{array}{l}\text { Di kampus saya, mahasiswa dapat menghabiskan waktu untuk membangun } \\
\text { kepercayaan satu sama lain. }\end{array}$ \\
\hline LC3 & $\begin{array}{l}\text { Di kampus saya, tim / kelompok merevisi pemikiran mahasiswa sebagai hasil dari } \\
\text { diskusi kelompok atau informasi yang dikumpulkan. }\end{array}$ \\
\hline LC4 & $\begin{array}{l}\text { Kampus saya membuat materi perkuliahan yang dipelajari tersedia bagi semua } \\
\text { mahasiswa. }\end{array}$ \\
\hline LC5 & Kampus saya mengakui para mahasiswa yang memiliki inisiatif \\
\hline LC6 & Di kampus saya, para mahasiswa terus mencari peluang untuk belajar. \\
\hline
\end{tabular}

Tabel 4. Instrumen Penelitian Variabel Knowledge Sharing

\begin{tabular}{|c|c|}
\hline Item & Pernyataan \\
\hline KS1 & $\begin{array}{l}\text { Menggunakan online learning untuk berbagi pengetahuan terkait pembelajaran } \\
\text { sangat penting untuk perkuliahan saya. }\end{array}$ \\
\hline KS2 & $\begin{array}{l}\text { Sangat menarik menggunakan online learning untuk berbagi pengetahuan dalam } \\
\text { perkuliahan. }\end{array}$ \\
\hline KS3 & $\begin{array}{l}\text { Menggunakan online learning untuk berbagi pengetahuan terkait perkuliahan } \\
\text { membantu saya up-to-date terhadap pengetahuan baru. }\end{array}$ \\
\hline KS4 & $\begin{array}{l}\text { Dengan menggunakan online learning untuk berbagi pengetahuan, saya dapat } \\
\text { memberikan kontribusi lebih banyak untuk perkuliahan. }\end{array}$ \\
\hline KS5 & $\begin{array}{l}\text { Saya dapat bertukar pengetahuan dalam perkuliahan dengan teman melalui online } \\
\text { learning. }\end{array}$ \\
\hline KS6 & $\begin{array}{l}\text { Saya senang menggunakan online learning untuk berbagi pengetahuan dalam } \\
\text { perkuliahan. }\end{array}$ \\
\hline
\end{tabular}

\section{c. Analisis Data}

Penelitian ini menggunakan pendekatan kuantitatif untuk menjawab pertanyaan penelitian. Adapun cara yang digunakan untuk melakukan analisis data yaitu menggunakan uji regresi linier berganda. Uji tersebut dapat digunakan dalam proses perhitungan untuk mengetahui besarnya pengaruh dua variabel bebas atau lebih (variabel independen) terhadap satu variabel terikat (dependen) serta melakukan prediksi variabel terikat dengan menggunakan dua atau lebih variabel bebas tersebut. Dalam penelitian ini variabel yang digunakan yaitu variabel independen (terdiri dari perceived enjoyment (X1), perceived reciprocal benefit (X2), dan learning culture (X3)) dan variabel dependen (knowledge sharing (Y)). Model analisis dalam penelitian ini dapat dituliskan dalam rumus matematika pada persamaan 1 sebagai berikut:

$\mathrm{Y}=\beta_{0}+\beta_{1} \mathrm{X}_{1}+\beta_{2} \mathrm{X}_{2}+\beta_{3} \mathrm{X}_{3}$ 
Keterangan:

Y: Knowledge sharing

$\beta_{0}-\beta_{3:}$ koefisien regresi

$\mathrm{X}_{1}$ : Perceived enjoyment

$\mathrm{X}_{2}$ : Perceived reciprocal benefit

$\mathrm{X}_{3}$ : Learning culture

Setelah dilakukan analisis regresi linier berganda dilanjutkan dengan analisis uji $\mathrm{t}$ guna memperoleh informasi terkait pengaruh variabel bebas terhadap variabel terikat secara parsial. Penelitian ini berguna untuk mengetahui apakah variabel perceived enjoyment, perceived reciprocal benefit dan learning culture secara parsial berpengaruh terhadap variabel knowledge sharing pada kuliah online di Universitas XYZ. Kriteria untuk hasil pengujian yaitu dengan menganalisis pada nilai $\mathrm{T}_{\text {hitung }}$ lebih besar dari $\mathrm{T}_{\text {tabel }}$ maka secara parsial ketiga variabel independen berpengaruh secara positif terhadap variabel dependen pada nilai signifikansi 5\%. Tahap selanjutnya adalah melakukan uji $\mathrm{F}$ untuk memperoleh informasi akan pengaruh variabel independen terhadap variabel dependen secara bersama-sama atau simultan. Penelitian ini berguna untuk mengetahui apakah variabel perceived enjoyment, perceived reciprocal benefit dan learning culture secara simultan berpengaruh terhadap variabel knowledge sharing pada kuliah online di Universitas XYZ. Kriteria untuk hasil pengujian yaitu dengan menganalisis pada nilai $\mathrm{F}_{\text {hitung }}$ lebih besar dari $\mathrm{F}_{\text {tabel }}$ maka secara silmultan ketiga variabel independen berpengaruh positif terhadap variabel dependen dengan nilai signifikansi adalah $5 \%$. Selain itu dilakukan juga analisis uji asumsi klasik untuk meramalkan hasil dari model regresi. Sebab model regresi yang baik sebaiknya memiliki tingkat kesalahan yang seminimal mungkin. Untuk mengetahui kondisi tersebut, peneliti menggunakan beberapa asumsi klasik seperti normalitas, heteroskedastisitas, dan multikolinieritas. Untuk pengujian normalitas dalam penelitian ini memiliki tujuan untuk peroleh informasi terkait model dalam regresi yang diolah apakah berdistribusi normal atau sebaliknya. Peneliti menggunakan uji One Sample Kolmogorov Smirnov guna mengetahui normalitas suatu data. Selanjutnya pengujian heteroskedastisitas dalam penelitian ini dipakai untuk memperoleh informasi mengenai varian residual yang tidak sama di setiap pengamatan pada model regresi. Sebab model regresi yang baik sebaiknya tidak mengalami heterokedastisitas. Untuk uji asumsi ini nantinya akan dicek menggunakan uji glejser. Terakhir pengujian multikolinieritas dipakai untuk mengelola data apakah terdapat relasi yang tinggi antar variabel independen. Jika ternyata diperoleh korelasi yang tinggi antar variabel independen maka bisa berakibat bahwa variabel bebas dengan variabel terikat terganggu. Dengan demikian sebagai deteksi awal untuk mengetahui ada tidaknya multikolinieritas digunakan variance inflation factor (VIF).

\section{Hasil dan Pembahasan}

Hasil dan pembahasan mengenai pengujian kuesioner sebagai berikut.

\section{a. Karakteristik Responden}

Berdasarkan penyebaran kuesioner yang telah dibagikan, gambar 2 berikut menunjukkan besarnya prosentase partisipan mahasiswa yang merupakan sampel dalam penelitian ini. Diperoleh hasil bahwa jumlah sampel dari mahasiswa prodi Sistem Informasi angkatan 2018 sebanyak 21,9\%, angkatan 2019 sebanyak 38,7\%, dan angkatan 2020 sebanyak 39,4\%.

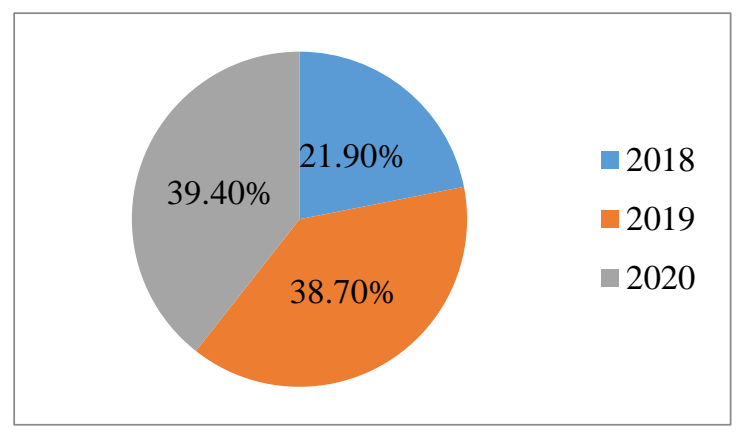

Gambar 2. Prosentase Jumlah Responden 


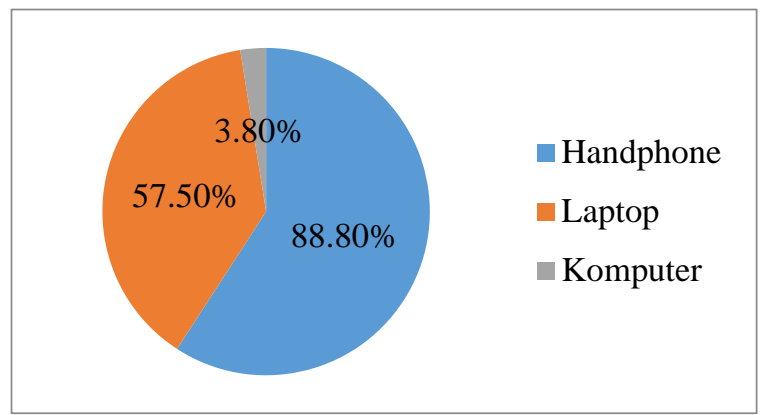

\section{Gambar 3. Prosentase Media Penunjang Kuliah Online}

Selanjutnya untuk media yang digunakan dalam kuliah online (lihat Gambar 3) antara lain handphone dengan prosentase $88,8 \%$, laptop dengan prosentase $57,5 \%$, dan komputer dengan prosentase $3,8 \%$. Hal tersebut dapat membuktikan bahwa mahasiswa cenderung menggunakan perangkat handphone sebagai media untuk menunjang perkuliahan secara online. Pemilihan device yang tepat juga penting untuk diperhatikan sebab untuk memastikan bahwa tidak ada mahasiswa yang tertinggal dan juga memastikan proses kegiatan perkuliahan berhasil dilaksanakan [22].

\section{b. Uji Regresi Linier Berganda}

Tabel 5. Tabel Uji Regresi Linier Berganda

\begin{tabular}{|c|c|c|c|c|c|c|}
\hline \multirow{2}{*}{\multicolumn{2}{|c|}{ Model }} & \multicolumn{2}{|c|}{$\begin{array}{l}\text { Unstandardized } \\
\text { Coefficients }\end{array}$} & \multirow{2}{*}{$\begin{array}{l}\text { Standardized } \\
\text { Coefficients } \\
\text { Beta }\end{array}$} & \multirow[b]{2}{*}{$\mathrm{t}$} & \multirow[b]{2}{*}{ Sig. } \\
\hline & & B & Std. Error & & & \\
\hline \multirow[t]{4}{*}{1} & (Constant) & 1,954 & 1,391 & & 1,405 & 162 \\
\hline & Perceived Enjoyment (X1) & 631 & ,066 & 612 & 9,517 & ,000 \\
\hline & Perceived Reciprocal (X2) &, 107 &, 084 & ,092 & 1,280 & ,202 \\
\hline & Learning Culture (X3) & 206 & .070 & .189 & 2.964 & .004 \\
\hline
\end{tabular}

a. Dependent Variable: Knowledge Sharing (Y)

Berdasarkan analisis data menggunakan SPSS 22 pada tabel 5 di atas, maka diperoleh hasil persamaan regresi sebagai berikut:

$Y=1,954+0,631 X_{1}+0,107 X_{2}+0,206 X_{3}$

Persamaan regresi memperlihatkan keterkaitan antara variabel independen dengan variabel dependen secara parsial, dari persamaan nomor 2 di atas maka dapat diambil kesimpulan bahwa nilai konstanta diperoleh sebesar 1,954 menunjukkan bahwa apabila tidak terjadi perubahan pada variabel perceived enjoyment, perceived reciprocal benefit, dan learning culture (nilai $\mathrm{X}_{1}, \mathrm{X}_{2}$, dan $\mathrm{X}_{3}$ adalah 0) maka knowledge sharing pada kuliah online Universitas $\mathrm{XYZ}$ adalah sebesar 1,954 satuan. Selanjutnya nilai koefisien regresi variabel perceived enjoyment sebesar 0,631 yang menunjukkan jika variabel perceived enjoyment $\left(\mathrm{X}_{1}\right)$ meningkat $1 \%$ dengan asumsi variabel perceived reciprocal benefit $\left(\mathrm{X}_{2}\right)$, variabel learning culture $\left(\mathrm{X}_{3}\right)$, dan konstanta (a) adalah 0 (nol), maka knowledge sharing pada kuliah online Universitas XYZ meningkat sebesar 0,631. Hal ini membuktikan bahwa variabel perceived enjoyment yang disediakan berkontribusi secara positif bagi knowledge sharing dalam kuliah online, sehingga semakin kompleks perceived enjoyment yang diberikan di Universitas XYZ, maka semakin tinggi pula tingkat knowledge sharing yang dirasakan oleh mahasiswa. 
Nilai koefisien regresi variabel perceived reciprocal benefit adalah 0,107 yang menunjukkan jika variabel perceived reciprocal benefit $\left(\mathrm{X}_{2}\right)$ meningkat $1 \%$ dengan asumsi variabel perceived enjoyment $\left(\mathrm{X}_{1}\right)$, variabel learning culture $\left(\mathrm{X}_{3}\right)$, dan konstanta (a) adalah 0 (nol), maka knowledge sharing pada kuliah online Universitas XYZ meningkat sebesar 0,107. Hal ini membuktikan bahwa variabel perceived reciprocal benefit yang disediakan memiliki kontribusi positif bagi knowledge sharing, sehingga semakin kompleks perceived reciprocal benefit yang diberikan di Universitas XYZ, maka semakin tinggi pula tingkat knowledge shring yang dirasakan oleh mahasiswa.

Nilai koefisien regresi variabel learning culture sebesar 0,206 yang menunjukkan jika variabel learning culture $\left(\mathrm{X}_{3}\right)$ meningkat $1 \%$ dengan asumsi variabel perceived enjoyment $\left(\mathrm{X}_{1}\right)$, variabel perceived reciprocal benefit $\left(\mathrm{X}_{2}\right)$, dan konstanta (a) adalah 0 (nol), maka knowledge sharing pada kuliah online Universitas XYZ meningkat sebesar 0,206. Hal ini membuktikan bahwa variabel learning culture yang disediakan memiliki kontribusi positif bagi knowledge sharing, sehingga semakin tinggi learning culture yang diberikan di Universitas XYZ, maka semakin tinggi pula tingkat knowledge sharing yang dirasakan oleh mahasiswa.

\section{c. Hasil Uji t}

Berdasarkan tabel 5 di atas dengan melihat baris, kolom $\mathrm{t}$, dan sig dapat dijelaskan bahwa dengan nilai $\mathrm{T}_{\text {tabel }}$ pada tabel statistik dengan signifikansi $0,05 / 2=0,025$ dan derajat kebebasan $\mathrm{df}=\mathrm{n}-\mathrm{k}-1=$ 160-3-1 = 156, maka akan diperoleh hasil untuk $\mathrm{T}_{\text {tabel }}$ sebesar 1,97529. Sehingga hasil uji $\mathrm{t}$ dapat dijabarkan sebagai berikut:

1) Variabel perceived enjoyment $\left(\mathrm{X}_{1}\right)$ berpengaruh secara positif dan signifikan terhadap knowledge sharing pada kuliah online di Universitas XYZ. Hal tersebut telihat dari nilai signifikansi perceived enjoyment $\left(\mathrm{X}_{1}\right) \quad 0,000<0,05$. Berarti nilai $\mathrm{T}_{\text {hitung }}$ lebih besar dari $\mathrm{T}_{\text {tabel }}(9,517>$ 1,97529). Dengan demikian $\mathrm{H}_{0}$ ditolak dan $\mathrm{H}_{\mathrm{a}}$ diterima. Sehingga hipotesis yang berbunyi terdapat pengaruh perceived enjoyment terhadap knowledge sharing $\left(\mathrm{H}_{1}\right)$ secara parsial diterima.

2) Selanjutnya variabel perceived reciprocal benefit $\left(\mathrm{X}_{2}\right)$ berpengaruh secara negatif dan tidak signifikan terhadap knowledge sharing pada kuliah online di Universitas XYZ. Hal tersebut telihat dari signifikansi perceived reciprocal benefit $\left(\mathrm{X}_{2}\right)$ 0,202 $>0,05$. Berarti nilai $\mathrm{T}_{\text {hitung }}$ lebih kecil dari $\mathrm{T}_{\text {tabel }}(1,280<1,97529)$ maka $\mathrm{H}_{0}$ diterima dan $\mathrm{H}_{\mathrm{a}}$ ditolak. Sehingga hipotesis yang berbunyi terdapat pengaruh perceived reciprocal benefit terhadap knowledge sharing $\left(\mathrm{H}_{2}\right)$ secara parsial tidak diterima.

3) Sedangkan variabel learning culture $\left(\mathrm{X}_{3}\right)$ berpengaruh secara positif dan signifikan terhadap knowledge sharing pada kuliah online di Universitas XYZ. Hal tersebut telihat dari signifikansi learning culture $\left(\mathrm{X}_{3}\right) \quad 0,004<0,05$. Dengan demikian nilai $\mathrm{T}_{\text {hitung }}$ lebih besar dari $\mathrm{T}_{\text {tabel }}(2,964>$ 1,97529). Dapat disimpulkan $\mathrm{H}_{0}$ ditolak dan $\mathrm{H}_{\mathrm{a}}$ diterima. Sehingga hipotesis yang berbunyi terdapat pengaruh learning culture terhadap knowledge sharing $\left(\mathrm{H}_{3}\right)$ secara parsial diterima.

Dapat diambil kesimpulan bahwa dengan melakukan uji t, peneliti dapat mengetahui variabel apa saja yang berpengaruh terhadap niat mahasiswa untuk mau melakukan knowledge sharing dalam proses perkuliahan secara online atau daring. Variabel yang berpengaruh kuat adalah perceived enjoyment. Sebab pelaksanaan kuliah online dapat dilakukan dimanapun dan tidak terbatas oleh ruang dan waktu. Selain itu mahasiswa juga dapat mencari informasi secara langsung dari sumber internet untuk membantu mereka dalam menunjang belajar. Kemudian untuk variabel yang cukup berpengaruh yaitu learning culture. Dalam hal ini, mahasiswa akan cenderung untuk mau melakukan knowledge sharing jika ada topik mengenai studi kasus. Selain itu mereka akan lebih aktif untuk berbagi pengetahuan jika ada reward yang nantinya diberikan seperti nilai bonus atau nilai keaktifan mahasiswa. Dengan menerapkan learning culture yang baik dapat meningkatkan produktifitas mahasiswa untuk mau berpartisipasi aktif dalam perkuliahan. Adapun yang tidak memiliki pengaruh kuat atau lemah adalah variabel perceived reciprocal benefit. Hal tersebut dapat dilihat secara fakta bahwa sebagian besar mahasiswa merasa jenuh atau bosan melakukan perkuliahan secara online. Sebab materi yang dipelajari lebih mutlak untuk dipelajari secara mandiri dan juga rendahnya tingkat interaksi satu sama lain sehingga mengakibatkan banyaknya perbedaan persepsi. 


\section{d. Hasil Uji F}

Uji ini dilakukan dengan cara membandingkan nilai $F_{\text {hitung }}$ lebih besar dari $F_{\text {tabel }}$ maka model yang dirumuskan sudah tepat. Jika nilai $F_{\text {hitung }}>F_{\text {tabael }}$ maka dapat diartikan bahwa model regresi sudah tepat yang artinya terdapat pengaruh secara bersama. Nilai $\mathrm{F}_{\text {tabel }}$ dapat dilihat dari tabel statistik pada tingkat signifikansi 0,05 dengan df 1 (jumlah variabel-1) = 3, dan df 2 (n-k-1) atau 160-3-1 = 156 (n adalah jumlah data dan $\mathrm{k}$ adalah jumlah variabel independen). Sehingga diperoleh hasil untuk $F_{\text {tabel }}$ sebesar 2,66.

Berdasarkan hasil pengujian pada tabel 6 di bawah dapat diketahui pada nilai $F_{\text {hitung }}$ sebesar 87,672. Adapun nilai $F_{\text {tabel }}$ sebesar 2,66. Dengan demikian nilai $F_{\text {hitung }}>F_{\text {tabel }}$ atau 87,672 $>2,66$ dan tingkat signifikan $0,000<0,05$ maka $\mathrm{H}_{0}$ ditolak dan $\mathrm{H}_{\mathrm{a}}$ diterima, dapat dijelaskan bahwa variabel perceived enjoyment $\left(\mathrm{X}_{1}\right)$, perceived reciprocal benefit $\left(\mathrm{X}_{2}\right)$, dan learning culture $\left(\mathrm{X}_{3)}\right.$ secara bersamaan berpengaruh signifikan terhadap knowledge sharing pada kuliah online di Universitas $\mathrm{XYZ}(\mathrm{Y})$.

Uji F pada penelitian ini perlu untuk dilakukan sebab peneliti menggunakan tiga variabel bebas atau independen. Dengan melakukan uji ini, peneliti dapat memberikan kesimpulan bahwa ketiga variabel bebas yang sudah diuji memberikan pengaruh signifikan terhadap knowledge sharing. Hal ini menunjukkan bahwa ketiga variabel bebas tersebut layak dan dapat dilanjutkan dengan melakukan pengujian selanjutnya.

Tabel 6. Tabel Uji Anova

\begin{tabular}{|c|c|c|c|c|c|}
\hline Model & Sum of Squares & $\mathrm{df}$ & Mean Square & $\mathrm{F}$ & Sig. \\
\hline 1 Regression & 1885,548 & 3 & 628,516 & $\begin{array}{l}87,6 \\
72\end{array}$ & $.000^{\mathrm{b}}$ \\
\hline Residual & 1118,352 & 156 & 7,169 & & \\
\hline Total & 3003,900 & 159 & & & \\
\hline
\end{tabular}

a. Dependent Variable: Knowledge Sharing (Y)

b. Predictors: (Constant), Learning Culture (X3), Perceived Enjoyment (X1), Perceived Reciprocal (X2)

e. Hasil Uji Normalitas

Tabel 7. Hasil Uji One-Sample Kolmogorov-Smirnov

\begin{tabular}{lll}
\hline & & Unstandardized Residual \\
\hline $\mathrm{N}$ & & 160 \\
Normal Parameters $^{\mathrm{a}, \mathrm{b}}$ & Mean & .0000000 \\
& Std. Deviation & 2.65210495 \\
Most Extreme Differences & Absolute & .068 \\
& Positive & .068 \\
& Negative & -.064 \\
Test Statistic & & .068 \\
Asymp. Sig. (2-tailed) & & $.068^{\mathrm{c}}$ \\
\hline
\end{tabular}

a. Test distribution is Normal.

b. Calculated from data.

c. Lilliefors Significance Correction.

Untuk menguji normalitas data, peneliti menggunakan teknik uji one-sample kolmogorovsmirnov sebab uji ini tergolong sederhana dan tidak menimbulkan banyak persepsi dari hasil uji normalitas menggunakan grafik. Adapun syarat suatu model regresi dikatakan baik apabila datanya terdistribusi normal. Dalam penelitian ini, berdasarkan hasil uji pada tabel 7 di atas dapat diketahui bahwa nilai signifikansi (Asymp. Sig. (2-tailed) sebesar 0,068. Hal tersebut menunjukkan bahwa nilai signifikansi lebih besar dari 0,05. Dengan demikian nilai residual terdistribusi dengan normal. Sehingga hasil uji normalitas ini menunjukkan bahwa model regresi yang diajukan adalah baik. 


\section{f. Hasil Uji Heterokedastisitas}

Dalam suatu uji asumsi klasik, salah satu pelanggaran yang kerap kali terjadi adalah terjadinya heterokedastisitas. Heterokedastisitas dapat terjadi apabila varian dari error dari suatu pengamatan ke pengamatan lain terjadi ketidaksamaan. Apabila heterokedastisitas tidak segera diatasi maka dapat menimbulkan berbagai permasalahan yang cukup serius. Oleh sebab itu, peneliti menggunakan uji glejser untuk menguji heterokedastisitas tersebut. Dari hasil pengujian glejser berdasarkan tabel 8 di bawah, diperoleh bahwa nilai signifikansi ketiga variabel independen lebih dari 0,05. Sehingga dapat disimpulkan bahwa tidak terjadi masalah heterokedastisitas pada model regresi. Dengan demikian dapat dijelaskan bahwa model regresi yang diajukan memiliki model regresi yang baik sebab tidak terjadinya heterokedastisitas.

Tabel 8. Hasil Uji Glejser

\begin{tabular}{|c|c|c|c|c|c|}
\hline \multirow[b]{2}{*}{ Model } & \multicolumn{2}{|c|}{$\begin{array}{l}\text { Unstandardized } \\
\text { Coefficients }\end{array}$} & \multicolumn{2}{|c|}{$\begin{array}{l}\text { Standardized } \\
\text { Coefficients }\end{array}$} & \multirow[b]{2}{*}{ Sig. } \\
\hline & $\bar{B}$ & Std. Error & Beta & $\mathrm{t}$ & \\
\hline 1 (Constant) & 3.665 & .936 & & 3.916 & .000 \\
\hline (X1) & -.018 & .045 & -.042 & -.407 & .684 \\
\hline (X2) & -.056 & .056 & -.115 & -.987 & .325 \\
\hline (X3) & -.012 & .047 & -.025 & -.248 & .805 \\
\hline
\end{tabular}

\section{g. Hasil Uji Multikolinieritas}

Dari tabel 9 di bawah (hasil uji variabce inflation factor) dapat diberikan kesimpulan bahwa dari ketiga variabel bebas perceived enjoyment, perceived reciprocal benefit, dan learning culture $\left(\mathrm{X}_{1}, \mathrm{X}_{2}\right.$, dan $\mathrm{X}_{3}$ ) masing-masing memiliki nilai tolerance lebih dari 0,1 dan memiliki nilai VIF kurang dari 10. Dengan demikian, maka dapat disimpulkan bahwa tidak terjadi multikolinieritas antar variabel bebas. Sehingga dapat dikatakan bahwa setiap variabel bebas tidak memiliki hubungan atau korelasi yang kuat dengan variabel bebas yang lain. Dengan kata lain, semua variabel bebas yang digunakan dalam penelitian ini tidak memiliki masalah multikolinieritas. Sebab apabila hasil uji mengalami multikolinieritas dapat menyebabkan bahwa variabel bebas yang diajukan tidak memiliki pengaruh terhadap variabel terikat.

Tabel 9. Hasil Uji Variance Inflation Factor

\begin{tabular}{llllll}
\hline & \multicolumn{2}{l}{$\begin{array}{l}\text { Unstandardized } \\
\text { Coefficients }\end{array}$} & $\begin{array}{l}\text { Standardized } \\
\text { Coefficients }\end{array}$ & \multicolumn{2}{l}{$\begin{array}{l}\text { Collinearity } \\
\text { Statistics }\end{array}$} \\
\cline { 2 - 6 } Model & $\mathrm{B}$ & Std. Error & Beta & Tolerance & VIF \\
\hline 1 (Constant) & 1.954 & 1.391 & & & \\
(X1) & .631 & .066 & .612 & .576 & 1.735 \\
(X2) & .107 & .084 & .092 & .461 & 2.168 \\
(X3) & .206 & .070 & .189 & .589 & 1.698 \\
\hline
\end{tabular}

a. Dependent Variable: Knowledge Sharing (Y)

\section{Kesimpulan}

Penelitian ini dilakukan untuk melakukan analisis perceived enjoyment, perceived reciprocal benefit, dan learning culture terhadap knowledge sharing yang dilakukan pada kuliah online di Universitas XYZ. Berdasarkan hasil pengolahan data dapat diambil kesimpulan sebagai berikut: (1) Variabel perceived enjoyment berpengaruh positif terhadap knowledge sharing dalam perkuliahan secara online. Hal tersebut menunjukkan bahwa semakin baik tingkat perceived enjoyment dalam menggunakan kuliah online maka dapat meningkatkan keefektifan dan keaktifan mahasiswa untuk melakukan knowledge ssharing. Dengan demikian pihak Universitas XYZ dapat memaksimalkan penggunaan media kuliah online yang saat ini digunakan dengan menyesuaikan media yang lebih diminati atau lebih disukai mahasiswa. (2) Variabel learning culture berpengaruh positif terhadap knowledge sharing dalam perkuliahan secara online. Hal tersebut menunjukkan bahwa semakin baik 
tingkat learning culture dalam kuliah online maka dapat memotivasi mahasiswa untuk senantiasa mau untuk berbagi pengetahuan. Pihak Universitas XYZ dapat memaksimalkan learning culture seperti dengan menambah aturan bahwa mahasiswa diharuskan membaca atau menonton video pembelajaran sebelum perkuliahan dimulai. (3) Variabel perceived reciprocal benefit tidak berpengaruh terhadap knowledge sharing. Hal tersebut menunjukkan bahwa penggunaan sistem untuk menunjang kuliah online kurang diminati oleh sebagian besar mahasiswa. Hal tersebut dapat dilihat dari jumlah penggunaan handphone yang lebih dominan dibanding laptop ataupun komputer. Sebab piranti tersebut memiliki keterbatasan dalam waktu penggunaan dan ukuran layar yang terlalu kecil (dapat mengakibatkan tulisan kurang mudah terbaca dan kurang leluasa dalam penggunaannya). Beberapa saran yang dapat diberikan untuk mengembangkan penelitian ini, antara lain: (1) Variabel-variabel penelitian dapat ditambahkan dengan mengacu pada faktor-faktor yang mempengaruhi berbagi pengetahuan dalam perkuliahan secara online atau daring. (2) Penelitian ini dapat dikembangkan untuk menghasilkan suatu prototipe untuk sistem kuliah online dengan konsep database tunggal yang mampu menjembatani antara dosen dan mahasiswa secara langsung sekaligus dengan penambahan fitur seperti sistem repositori untuk mendokumentasikan pengetahuan yang pernah dibagikan.

\section{Referensi}

[1] N. M. Alqudah, H. M. Jammal, O. Saleh, Y. Khader, and N. Obeidat, "Perception and Experience of Academic Jordanian Ophtalmologists With E-Learning for Undergraduate Course During The Covid-19 Pandemic," Ann. Med. Surg., vol. 59, pp. 44-47, 2020, doi: 10.1016/j.amsu.2020.09.014.

[2] L. Mishra, T. Gupta, and A. Shree, "Online Teaching-Learning in Higher Education During Lockdown Period of Covid-19 Pandemic," Int. J. Educ. Res. Open, vol. 1, p. 100012, 2020, doi: 10.1016/j.ijedro.2020.100012.

[3] K. Y. Tung, Memahami Knowledge Management. Jakarta: Penerbit Indeks, 2018.

[4] I. B. Fernandez and R. Sabherwal, Knowledge Management: Systems and Processes. United States of America: M.E.Sharpe, Inc, 2010.

[5] L. D. Paderanga, "Classroom Video Conferencing: Its Contribution to Peace Education," Procedia - Soc. Behav. Sci., vol. 123, pp. 113-121, 2014, doi: 10.1016/j.sbspro.2014.01.1404.

[6] A. Cennet, "Perceptions of Undergraduate Students About Synchronous Video ConferenceBased English Courses," Procedia - Soc. Behav. Sci., vol. 199, pp. 627-633, 2015, doi: 10.1016/j.sbspro.2015.07.589.

[7] S. A. Aderibigbe, "Can Online Discussions Facilitate Deep Learning for Students in General Education?," Heliyon, vol. 7, pp. 1-6, 2021.

[8] N. R. Alsalhi, S. Al-Qatawneh, M. Eltahir, F. Althunibat, and K. Alharrah, "The Role of Academic Electronic Books in Undergraduate Students' Achievement in Higher Education," Heliyon, vol. 6, pp. 1-12, 2020, doi: 10.1016/j.heliyon.2020.e05550.

[9] T. Muthuprasad, S. Aiswarya, K. S. Aditya, and G. K. Jha, "Students' Perception and Preference for Online Education in India During COVID -19 Pandemic," Soc. Sci. Humanit. Open, vol. 3, no. 1, pp. 1-11, 2021, doi: 10.1016/j.ssaho.2020.100101.

[10] T. Vagg, J. Y. Balta, A. Bolger, and M. Lone, "Multimedia in Education: What Do The Students Think?," Heal. Prof. Educ., vol. 6, pp. 325-333, 2020, doi: 10.1016/j.hpe.2020.04.011.

[11] S. Moghavvemi, M. Sharabati, T. Paramanathan, and N. M. Rahin, "The Impact Of Perceived Enjoyment, Perceived Reciprocal Benefits And Knowledge Power On Students' Knowledge Sharing Through Facebook," Int. J. Manag. Educ., vol. 15, pp. 1-12, 2017, doi: 10.1016/j.ijme.2016.11.002.

[12] A. R. Ahmad, A. S. Jameela, and M. B. Raewf, "Impact of Social Networking and Technology on Knowledge Sharing among Undergraduate Students," Int. Bus. Educ. J., vol. 14, no. 1, pp. 116, 2021, [Online]. Available: https://www.academia.edu/download/65493058/document.pdf.

[13] N. Hussein, M. K. Omar, and M. A. Zayadah, "IT Usage, Perceived Knowledge Usefulness, Learning Culture and Intention to Share Knowledge among Business Students in a Malaysian Public University," Procedia - Soc. Behav. Sci., vol. 219, pp. 324-329, 2016, doi: 10.1016/j.sbspro.2016.04.039. 
[14] M. M. Naqshbandi and I. Tabche, "The Interplay Of Leadership, Absorptive Capacity, And Organizational Learning Culture In Open Innovation: Testing A Moderated Mediation Model," Technol. Forecast. Soc. Change, vol. 133, pp. 156-167, 2018, doi: 10.1016/j.techfore.2018.03.017.

[15] Saifudin, "Pengaruh Implementasi Software Akuntansi Terhadap Kinerja Perangkat Desa Dengan Perceived Enjoyment Sebagai Variabel Intervening," J. Ilm. Pendidik. Ekon., vol. 3, no. 2, pp. 60-70, 2018, doi: 10.26877/ep.v3i2.3219.

[16] M. A. S. Oktarini and I. M. Wardana, "Peran Customer Satisfaction Memediasi Pengaruh Perceived Ease of Use dan Perceived Enjoyment Terhadap Repurchase Intention," E-Jurnal Manaj. Unud, vol. 7, no. 4, pp. 2041-2072, 2018.

[17] V. D. Phung and I. H. M. B. Binsawad, "Exploring How Environmental and Personal Factors Influence Knowledge Sharing Behavior Leads to Innovative Work Behavior," Proc. 26th Int. Conf. Inf. Syst. Dev. ISD 2017, no. January, 2017, doi: 10.1007/978-3-319-74817-7.

[18] S. Ibrahim and L. H. Heng, "The Roles of Learning in Stimulating Knowledge Sharing at SMEs," Procedia - Soc. Behav. Sci., vol. 172, pp. 230-237, 2015, doi: 10.1016/j.sbspro.2015.01.359.

[19] E. C. K. Cheng, "Knowledge Sharing For Creating School Intellectual Capital," Procedia - Soc. Behav. Sci., vol. 191, no. 852, pp. 1455-1459, 2015, doi: 10.1016/j.sbspro.2015.04.307.

[20] N. Sriratanaviriyakul and J. El-Den, "Motivational Factors for Knowledge Sharing using Pedagogical Discussion Cases: Students, Educators, and Environmental Factors," Procedia Comput. Sci., vol. 124, pp. 287-299, 2017, doi: 10.1016/j.procs.2017.12.158.

[21] E. M. Sangadji and Sopiah, Metodologi Penelitian Pendekatan Praktis dalam Penelitian. Yogyakarta: Penerbit ANDI, 2010.

[22] R. M. Saidi, A. A. Sharipb, N. Z. Rahimc, Z. A. Zulkifli, and S. M. M. Zain, "Evaluating Students' Preferences of Open and Distance Learning (ODL) Tools," Procedia Comput. Sci., vol. 179, pp. 955-961, 2021, doi: 10.1016/j.procs.2021.01.085. 